\title{
Foliar Calcium Applications Do Not Improve Quality or Shelf Life of Strawberry, Raspberry, Blackberry, or Blueberry Fruit
}

\author{
Amanda J. Vance ${ }^{1}$ \\ Department of Horticulture and the North Willamette Research and \\ Extension Center, Oregon State University, 4017 ALS, Corvallis, OR 97331
}

Patrick Jones ${ }^{1}$

North Willamette Research and Extension Center, Oregon State University, 15210 NE Miley Road, Aurora, OR 97002

\author{
Bernadine C. Strik ${ }^{2,3}$ \\ Department of Horticulture, Oregon State University, 4017 ALS, Corvallis, \\ OR 97331
}

Additional index words. storage, postharvest, firmness, skin toughness, Fragaria $\times$ ananassa, Rubus sp., Vaccinium corymbosum

Abstract. Foliar calcium (Ca) products are applied by many berry growers to enhance fruit quality and shelf life without evidence that these applications increase fruit $\mathrm{Ca}$ or impact fruit characteristics when applied at rates recommended on the product label. The objectives of this study were to determine if fruit or leaf $\mathrm{Ca}$ increases when several formulations of liquid Ca products are applied to developing fruit, and to assess any resulting changes in fresh market quality of berries. Products were applied in strawberry (Fragaria Xananassa L., 'Hood' and 'Albion'), raspberry (Rubus idaeus L., 'Tulameen' and 'Vintage'), blackberry (Rubus L. subgenus Rubus, Watson, 'Obsidian' and 'Triple Crown'), and blueberry (Vaccinium corymbosum L., 'Spartan', 'Liberty', 'Draper', and 'Legacy'). Calcium formulations tested were $\mathrm{Ca}$ chloride $\left(\mathrm{CaCl}_{2}\right), \mathrm{CaCl}_{2}+$ boron, $\mathrm{Ca}$ silicate, Ca chelate, and $\mathrm{Ca}$ acetate, which were compared with a water-only control. The rates used for each product were within ranges specified on the label and supplied equal amounts of $\mathrm{Ca}$ per ha for each treatment; the Ca concentration varied from $0.05 \%$ to $0.3 \%$ depending on the cultivar and the volume of water required for good coverage. All products were applied with a backpack sprayer, except in a separate trial where a backpack and electrostatic sprayer were compared in 'Draper' and 'Legacy'. Treatment applications were started at the early green fruit stage and were repeated three or four times, depending on duration of berry development and cultivar. Fruit were harvested into commercial clamshells 4 days to $\approx 4$ weeks after the final application of $\mathrm{Ca}$ from an early harvest at commercial ripeness. Data collected included berry weight, rating of fruit appearance and flavor, firmness, skin toughness, total soluble solids (TSS), and weight loss and nesting (collapse of fruit) during storage (evaluated at $\approx 5-, 10-, 15-$, and 20-days postharvest). Fruit and leaves were sampled at harvest to determine Ca concentration. There was no evidence of spotting or off-flavors due to Ca applications. Compared with the control, none of the Ca treatments or method of application changed leaf or fruit $\mathrm{Ca}$ concentration, fruit quality, firmness, or shelf life in any crop or cultivar tested.

The Pacific Northwest region of the United States is an important growing region for the production of blueberry $(V$. corymbosum L.), blackberry (Rubus L. subgenus

Received for publication 23 Nov. 2016. Accepted for publication $20 \mathrm{Jan} .2017$.

Mention of trade names or commercial products in this publication is solely for the purpose of providing specific information and does not imply recommendation or endorsement by Oregon State University.

${ }^{1}$ Faculty Research Assistant.

${ }^{2}$ Professor.

${ }^{3}$ Corresponding author. E-mail: bernadine.strik@ oregonstate.edu.
(Harkins et al., 2014) cultivars have been found to differ in fruit $\mathrm{Ca}$ concentration.

When soil Ca levels are sufficient, localized $\mathrm{Ca}$ deficiency such as in leaves or fruit may still become a problem in fruit crops. Calcium-related disorders include bitter pit in apple fruit (Malus domestica, Borkh.), blossom-end rot in tomato (Solanum lycopersicum L.) fruit, and tipburn in leaves of vegetables (Saure, 2005). These deficiencies in Ca may occur as a result of competition between vigorously growing shoots and fruit. Strik and Vance (2015) speculated that 'Draper' blueberry may have particularly low fruit $\mathrm{Ca}$ concentration due to the presence of many competing shoot tips during the fruit development period. Since $\mathrm{Ca}$ is translocated in the xylem and not the phloem, $\mathrm{Ca}$ is relatively immobile in the plant and tends to move predominantly to leaves, which have a high transpiration rate.

Penetration of $\mathrm{Ca}$ into fruit likely occurs through the stomata on the fruit surface. Penetration rates, however, have been shown to vary with cultivar, application method, and formulation of $\mathrm{Ca}$ used (Saure, 2005). The number of possible interactions that can affect $\mathrm{Ca}$ uptake and distribution in the plant is so complex that cultural management practices are not likely to increase fruit $\mathrm{Ca}$, without a direct application of $\mathrm{Ca}$ to the developing (Bangerth, 1979) or harvested (Hanson et al., 1993) fruit.

Postharvest dips with $\mathrm{CaCl}_{2}$ increased firmness and shelf life of raspberries and blueberries, but resulted in an unacceptable salty taste (Hanson et al., 1993; Montealegre and Valdes, 1993); washing or dipping fruit also removes the desirable, waxy bloom coating on blueberry fruit and decreases shelf life in blackberry, raspberry, and strawberry.

Foliar $\mathrm{Ca}$ applied to strawberries has been shown to delay fruit harvest, reduce incidence of fruit rot and improve fruit firmness (Cheour et al., 1990; Singh et al., 2007; Wójcik and Lewandowski, 2003). In blackberries, preharvest $\mathrm{Ca}$ applications did not impact initial fruit firmness following machine harvest, but had a positive effect during storage (Morris et al., 1980). Hanson (1995) applied $\mathrm{CaCl}_{2}$ to blueberry plants with minimal impact on fruit quality.

The objectives of this study were to test several Ca formulations with direct sprays of liquid products applied to developing fruit of strawberry, raspberry, blackberry, and blueberry cultivars and determine the impact on $\mathrm{Ca}$ concentrations of fruit and leaves, and fruit quality at harvest and during storage. Two methods of application were compared to assess the impact of spray coverage on these factors.

\section{Materials and Methods}

Two experiments were conducted: the first to study the impact of $\mathrm{Ca}$ formulation on several berry crops and cultivars and the second to study the effect of method of application. 


\section{Expt. 1}

The trial was conducted at two commercial farms (location 1: Cornelius, OR, lat. $45^{\circ} 47^{\prime} \mathrm{N}$, long. $123^{\circ} 05^{\prime} \mathrm{W}$; location 2 : Salem, OR, lat. $45^{\circ} 00^{\prime} \mathrm{N}$, long. $122^{\circ} 56^{\prime}$ W). Treatments were applied to commonly grown cultivars of each berry type, representing early and later fruiting seasons (Table 1). The plantings were mature and were managed per standard commercial practices (Barney et al., 2007; Hoashi-Erhardt and Walters, 2014; Pscheidt and Ocamb, 2016; Strik et al., 1993). In raspberry and blackberry, rows were spaced $3.0 \mathrm{~m}$ apart with a perennial grass grown in the aisles. Plants were drip irrigated, but overhead sprinklers were used for evaporative cooling when temperatures exceeded $29{ }^{\circ} \mathrm{C}$. Blueberry rows were also spaced $3.0 \mathrm{~m}$ apart with perennial grass between the rows. At location 1 , blueberry plants were overhead irrigated with sprinklers, whereas at location 2 , they were drip irrigated with overhead sprinklers used for evaporative cooling when temperatures exceeded $29^{\circ} \mathrm{C}$. In strawberry, 'Hood' was grown in a perennial matted row system with sprinkler irrigation, whereas 'Albion' was grown in a perennial plasticulture system with drip irrigation. All water sources used for irrigation and spray application were tested for $\mathrm{Ca}$ concentration (Table 2); none were found to have excessively high $\mathrm{Ca}$ that would possibly impact the results of this study.

Five commercially available Ca "foliar" products were evaluated at each location: $\mathrm{CaCl}_{2}$ (PhytaCal QC ${ }^{\text {TM}}$; California Organic Fertilizers, Fresno, CA), $\mathrm{CaCl}_{2}+$ boron (PhytaSet $\mathrm{QC}^{\mathrm{TM}}$; California Organic Fertilizers), calcium silicate (Mainstay $^{\mathrm{TM}}$, Redox Chemicals, Burley, ID); citric acid chelated calcium (Biomin ${ }^{\mathrm{TM}}$; JH Biotech Inc., Ventura, $\mathrm{CA}$ ), and calcium acetate (CalAce ${ }^{\mathrm{TM}}$; Cultivace, Salem, OR) (Table 3). A control where only water was applied was included. Rates of application for each $\mathrm{Ca}$ product were chosen to achieve the same rate of $\mathrm{Ca}$ applied per hectare $\left(336 \mathrm{~g} \cdot \mathrm{ha}^{-1}\right)$ while staying within the rates recommended on the product label (no recommended rates of water volume are typically provided). Calcium chloride was also applied at a high rate $\left(672 \mathrm{~g} \cdot \mathrm{ha}^{-1}\right)$, which did not exceed label recommendations. No surfactant was recommended for any of these products and thus none was added.

Treatments were applied with backpack sprayers (15-L capacity; Solo USA, Newport News, VA) pressurized to $\approx 414 \mathrm{kPa}$ and fitted with 80-02 EVS brass nozzles (TeeJet Technologies, Glendale Heights, IL). Applications were calibrated to achieve equal output volume for each plot. Volume of water applied was determined by typical grower practices and recommendations for the crop for stage of canopy cover (Table 3 ). Treatment applications began at the late bloom to early green fruit stage for each cultivar with the number of applications varying with the length of fruit development (fruit set to harvest period) for each berry crop and cultivar (Table 1). Preliminary results from

Table 1. Berry crops and cultivars included in Expts. 1 and 2 at locations 1 (Cornelius, OR), 2 (Salem, OR), and 3 (North Willamette Research and Extension Center, Aurora, OR), and dates of calcium treatment application and fruit harvest in 2015 .

\begin{tabular}{|c|c|c|c|c|c|c|c|}
\hline \multirow{2}{*}{$\frac{\text { Berry type }}{\text { Strawberry }}$} & \multirow{2}{*}{$\frac{\text { Cultivar }}{\text { Hood }}$} & \multirow{2}{*}{$\begin{array}{c}\text { Location } \\
1\end{array}$} & \multicolumn{4}{|c|}{ Application dates } & \multirow{2}{*}{$\begin{array}{l}\text { Harvest date } \\
27 \text { May }\end{array}$} \\
\hline & & & 29 Apr. & 7 May & 14 May & - & \\
\hline & Albion & 1 & 5 Aug. & 10 Aug. & 13 Aug. & - & 17 Aug. \\
\hline \multirow[t]{2}{*}{ Raspberry } & Tulameen & 1 & 20 May & 28 May & 4 June & - & 26 June \\
\hline & Vintage & 1 & 16 July & 24 July & 29 July & 一 & 3 Aug. \\
\hline \multirow[t]{2}{*}{ Blackberry } & Obsidian & 1 & 20 May & 28 May & 4 June & - & 22 June \\
\hline & Triple Crown & 1 & 18 June & 26 June & 2 July & - & 24 July \\
\hline \multirow[t]{6}{*}{ Blueberry } & Spartan & 1 & 29 Apr. & 14 May & 28 May & - & 19 June \\
\hline & Liberty & 1 & 29 Apr. & 14 May & 28 May & 11 June & 13 July \\
\hline & Draper & 2 & 7 May & 19 May & 3 June & 10 June & 6 July \\
\hline & Liberty & 2 & 7 May & 19 May & 3 June & 10 June & 10 July \\
\hline & Draper & 3 & 8 May & 24 May & 5 June & 12 June & 26 June \\
\hline & Legacy & 3 & 8 May & 24 May & 5 June & 12 June & 30 June \\
\hline
\end{tabular}

Table 2. Calcium concentration of water sources used for irrigation, evaporative cooling, and tank mixing of sprays for locations 1 (Cornelius, OR), 2 (Salem, OR), and 3 (North Willamette Research and Extension Center, Aurora, OR). Sprays were never mixed at location 2.

\begin{tabular}{llr}
\hline Location & \multicolumn{1}{c}{ Use } & Ca (ppm) \\
\hline 1 & Irrigation & 9.8 \\
1 & Irrigation & 7.7 \\
1 & Evaporative cooling & 19.9 \\
1 & Tank mixing & 17.3 \\
2 & Irrigation/evaporative cooling & 29.4 \\
3 & Irrigation & 23.8 \\
3 & Tank mixing & 20.2 \\
\hline
\end{tabular}

Table 3. Percent calcium (Ca) treatment for Expts. 1 and 2 at locations 1 (Cornelius, OR), 2 (Salem, OR), and 3 (North Willamette Research and Extension Center, Aurora, OR).

\begin{tabular}{lcccc}
\hline & \multicolumn{4}{c}{ Percent Ca applied } \\
\cline { 2 - 4 } Formulation & $748\left({\left.\mathrm{~L} \cdot h h^{-1}\right)^{\mathrm{z}}}\right.$ & $467\left(\mathrm{~L} \cdot \mathrm{ha}^{-1}\right)^{\mathrm{y}}$ & $234\left(\mathrm{~L} \cdot \mathrm{ha}^{-1}\right)^{\mathrm{x}}$ & $215\left(\mathrm{~L} \cdot \mathrm{ha}^{-1}\right)^{\mathrm{w}}$ \\
\hline Ca chloride (low) & 0.05 & 0.08 & 0.15 & 0.16 \\
Ca chloride (high) & 0.09 & 0.15 & 0.30 & - \\
Ca chloride + boron & 0.05 & 0.08 & 0.15 & - \\
Ca silicate & 0.05 & 0.08 & 0.15 & - \\
Ca chelate & 0.05 & 0.08 & 0.15 & - \\
Ca acetate & 0.05 & 0.08 & 0.15 & - \\
\hline
\end{tabular}

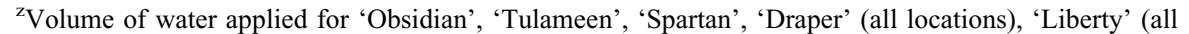
locations), and 'Legacy'.

'Volume of water applied for 'Hood', 'Vintage', and 'Triple Crown'.

${ }^{\mathrm{x}}$ Volume of water applied for 'Albion'.

wVolume of water applied with electrostatic sprayer (Expt. 2 only, 'Draper' and 'Legacy', location 3). Only Ca chloride (low) was tested.

early-season cultivars showed few differences among $\mathrm{Ca}$ treatments, so water volume was reduced to increase $\mathrm{Ca}$ concentration in later season cultivars (Table 3 ).

Experimental design. Treatments (Table 3) were arranged in a completely randomized design with four replicates of each experimental unit (plot) at each location. Plot size varied by crop $(9.1 \mathrm{~m}$ of row in strawberry, raspberry, and 'Obsidian' blackberry; and $6.1 \mathrm{~m}$ in 'Triple Crown' blackberry); in blueberry there were four plants per plot with one plant separating adjacent plots.

\section{Expt. 2}

The trial was conducted in a certified organic planting of 'Draper' and 'Legacy' blueberry at the North Willamette Research and Extension Center (location 3: Aurora, $\mathrm{OR}$, lat. $45^{\circ} 28^{\prime} \mathrm{N}$, long. $\left.122^{\circ} 76^{\prime} \mathrm{W}\right)$. Plants were $0.75 \mathrm{~m}$ apart in the row with $3.0 \mathrm{~m}$ between rows. A perennial grass was grown between the rows. Plants were drip irrigated, as needed. One $\mathrm{Ca}$ product $\left(\mathrm{CaCl}_{2}\right)$ was applied at the low rate $\left(336 \mathrm{~g} \cdot \mathrm{ha}^{-1}\right)$ (Table 3 ) using either a backpack sprayer (as previously described) at a concentration of $0.05 \%$ $\mathrm{Ca}\left(748 \mathrm{~L} \cdot \mathrm{ha}^{-1}\right.$ of water) or at a concentration of $0.16 \% \mathrm{Ca}$ using an electrostatic sprayer (215 L.ha ${ }^{-1}$ of water; On Target Spray Systems, Mt. Angel, OR) with two vertical booms each consisting of 13 nozzles. The experimental units (each a 5.3-m-long plot) were arranged in a randomized block design with cultivar and spray method as the main factors in a $2 \times 2$ factorial with two replicates.

Fruit harvest. In each experiment, fruit were harvested within $2 \mathrm{~d}$ of commercial harvest, which was determined by the grower collaborators (locations 1 and 2) and experience (location 3). Ripe fruit were harvested on one date from $4 \mathrm{~d}$ to $\approx 4$ weeks after the final treatment application (Table 1) and were handpicked directly into commercial polyethylene containers ("clamshells"; Sambrailo Packaging, Watsonville, CA) of standard size for each crop $(454,340$, and 170 $\mathrm{g}$ for strawberry, 'Tulameen' raspberry and 
Table 4. Fruit and leaf calcium (Ca, \%) at time of fruit harvest by treatment, crop, and cultivar for Expt. 1 at locations 1 (Cornelius, OR) and 2 (Salem, OR).

\begin{tabular}{|c|c|c|c|c|c|c|c|c|c|c|c|c|c|c|c|c|c|c|c|c|}
\hline \multirow[b]{3}{*}{ Treatment } & \multicolumn{4}{|c|}{ Strawberry (location 1) } & \multicolumn{4}{|c|}{ Raspberry (location 1) } & \multicolumn{4}{|c|}{ Blackberry (location 1) } & \multicolumn{4}{|c|}{ Blueberry (location 1) } & \multicolumn{4}{|c|}{ Blueberry (location 2) } \\
\hline & \multicolumn{2}{|c|}{ Hood } & \multicolumn{2}{|c|}{ Albion } & \multicolumn{2}{|c|}{ Tulameen } & \multicolumn{2}{|c|}{ Vintage } & \multicolumn{2}{|c|}{ Obsidian } & \multicolumn{2}{|c|}{ Triple Crown } & \multicolumn{2}{|c|}{ Spartan } & \multicolumn{2}{|c|}{ Liberty } & \multicolumn{2}{|c|}{ Liberty } & \multicolumn{2}{|c|}{ Draper } \\
\hline & Fruit & Leaf & Fruit & Leaf & Fruit & Leaf & Fruit & Leaf & Fruit & Leaf & Fruit & Leaf & Fruit & Leaf & Fruit & Leaf & Fruit & Leaf & Fruit & Lea \\
\hline $\begin{array}{l}\text { Ca chloride } \\
\text { (low) }\end{array}$ & 0.11 & 0.78 & 0.18 & 2.12 & 0.14 & 1.63 & 0.19 & 1.77 & 0.16 & 0.53 & 0.32 & 1.28 & 0.02 & 1.61 & 0.05 & 0.63 & 0.05 & 0.59 & 0.05 & 0.8 \\
\hline $\begin{array}{c}\text { Ca chloride } \\
\text { (high) }\end{array}$ & 0.10 & 0.80 & 0.17 & 2.12 & 0.14 & 1.78 & 0.22 & 1.80 & 0.15 & 0.51 & 0.27 & 1.39 & 0.02 & 1.86 & 0.06 & 0.59 & 0.05 & 0.62 & 0.05 & 0.8 \\
\hline $\begin{array}{l}\text { Ca chloride } \\
+ \text { boron }\end{array}$ & 0.10 & 0.78 & 0.18 & 2.36 & 0.14 & 1.73 & 0.23 & 1.77 & 0.15 & 0.52 & 0.28 & 1.20 & 0.02 & 1.55 & 0.05 & 0.57 & 0.05 & 0.62 & 0.05 & 0.8 \\
\hline Ca silicate & 0.10 & 0.75 & 0.18 & 2.35 & 14 & 1.69 & 0.23 & 1.83 & 16 & 0.52 & 0.32 & 1.36 & 0.03 & 1.73 & 0.05 & 0.5 & 0.05 & 0.61 & 0.06 & 0.9 \\
\hline $\mathrm{Ca} \mathrm{ch}$ & 0.10 & 0.80 & 0.15 & 2.43 & 0.14 & 1.70 & 0.21 & 1.88 & 0.15 & 0.47 & 0.31 & 1.32 & 0.02 & 1.73 & 0.05 & 0.60 & 0.05 & 0.63 & 0.05 & 0.8 \\
\hline $\mathrm{Ca}$ acetate & 0.10 & 0.74 & 0.16 & 2.19 & 0.17 & 1.52 & 0.25 & 1.85 & 0.16 & 0.49 & 0.30 & 1.25 & 0.04 & 1.75 & 0.05 & 0.58 & 0.04 & 0.65 & 0.05 & 0.8 \\
\hline $\begin{array}{l}\text { Control } \\
\text { (water) }\end{array}$ & 0.11 & 0.81 & 0.16 & 2.12 & 0.13 & 1.73 & 0.20 & 1.72 & 0.16 & 0.49 & 0.30 & 1.26 & 0.03 & 1.65 & 0.05 & 0.62 & 0.05 & 0.61 & 0.05 & 0.8 \\
\hline$P$ value & NS & NS & NS & NS & NS & NS & NS & NS & NS & NS & NS & NS & NS & NS & NS & NS & NS & NS & NS & NS \\
\hline
\end{tabular}

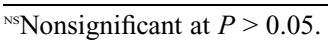

all blackberries, and 'Vintage' raspberry and all blueberries, respectively). A piece of white paper towel was placed in the bottom of each clamshell for strawberry, raspberry, and blackberry to simulate a soaking pad that is typically found in commercial packaging and to assist in visual ratings during storage. Clamshells were placed into coolers with ice packs and transported to the laboratory for data analysis (see below).

Tissue analysis. On the day of fruit harvest, a leaf tissue sample (most recent, fully expanded leaves) was collected for nutrient analysis per plot. In strawberry, 20 trifoliate leaves, including $\approx 10 \mathrm{~cm}$ of the petiole, were sampled. In raspberry and blackberry, 20 fruiting lateral leaves, and in blueberry, 50 leaves from shoots arising below the fruiting clusters, all including the petiole, were sampled per plot. Leaves were washed in distilled water, gently patted dry, and placed in paper bags before shipping by 2-d mail for analysis. One clamshell of fruit from each treatment plot was randomly selected for nutrient analysis. Strawberry and blueberry fruit were washed with distilled water and excess water shaken off before shipping, whereas raspberry and blackberry fruit were not washed (to maintain fruit integrity). Fruit samples, still in clamshells, were placed in zipper-top plastic bags in an insulated box with ice packs and shipped overnight for analysis. All tissue samples were analyzed by Brookside Laboratories (New Bremen, $\mathrm{OH}$ ) for $\mathrm{Ca}$ concentration using an inductively coupled plasma spectrophotometer after wet ashing the samples in nitric/perchloric acid (Gavlak et al., 1994).

Data collection and storage. Data collected on the day of fruit harvest included berry weight, rating of fruit appearance, firmness, skin toughness, and TSS (Brix). The berries were also tasted to determine the presence or absence of salty flavor from $\mathrm{CaCl}_{2}$ applications, which had been noted in previous work (Hanson et al., 1993; Montealegre and Valdes, 1993). Average berry weight was determined from 25 randomly selected fruit. Fruit appearance was subjectively rated on a 1 to 5 scale, with 1 being undamaged and 5 being the least marketable. All fruit harvested were intact and considered marketable, but aesthetic defects such as spotting caused by product application could result in a poorer rating. Average firmness was determined on 10 berries per experimental unit for strawberry, raspberry, and blackberry using a manual firmness tester [University of California manual firmness tester (serial no. 364; Western Industrial Supply, San Francisco, CA), with a mechanical force gauge (model LKG1; Ametek, Feasterville, PA), with a $1.2-\mathrm{cm}$ diameter tip]. Strawberry and blackberry fruit were compressed until one drop of juice was released. Raspberry fruit were compressed and firmness recorded when opposite sides of the torus touched. In blueberry, 25 berries were measured for firmness using a FirmTech 2 (BioWorks, Wamego, KS). Skin toughness was measured on 10 berries per experimental unit using a Correx 50-g tension gauge (Wagner Instruments, Greenwich, CT) with a blunt needle attached to determine the penetration force required to pierce the skin. In strawberry, the needle was placed on the shoulder of the berry between achenes. In raspberry and blackberry, the needle was placed in the center of a drupelet located midway between the top and bottom of the berry. In blueberry, the needle was placed at the widest diameter of the berry. Total soluble solids was measured on homogenized 10-berry samples from each experimental unit using a temperature compensated Palette digital refractometer (Atago USA, Bellevue, WA).

The impact of treatments on fruit storage ("shelf life") was assessed using a walk-in cooler maintained between 1.1 and $2.8^{\circ} \mathrm{C}$ for the duration of storage. However, temperature fluctuated from opening and closing of the cooler door and no humidity or atmospheric control was available. Clamshells were individually weighed before placing in cold storage and then again after 5 and $10 \mathrm{~d}$ of storage for strawberry, raspberry, and blackberry cultivars and $5,10,15$, and $20 \mathrm{~d}$ of storage for blueberry cultivars. Percent moisture loss was then calculated. In addition, fruit in each clamshell were measured for firmness, skin toughness, and TSS at each of the aforementioned storage times. Due to insufficient harvested fruit of 'Hood', TSS was only measured at harvest and firmness was not measured. In 'Vintage', commercial harvest occurred shortly before samples were taken and there was not enough fruit per plot to fill clamshells, which may have impacted measurements of moisture loss and firmness after storage. 'Draper' at location 2 was only sampled for laboratory analysis of $\mathrm{Ca}$ concentration; insufficient fruit were available for determination of quality at harvest and shelf life.

Data analysis. Data were analyzed using PROC MIXED (SAS version 9.3) for a completely randomized design (Expt. 1) and a randomized complete block design (Expt. 2). Mean separations were performed using Tukey's honestly significant difference test. When $\mathrm{Ca}$ treatments were not found to impact fruit quality parameters, data were pooled by cultivar. Within each crop, effects of cultivar and storage time on the measured variables were determined using a two-way analysis of variance. Since different clamshells were analyzed at each storage date, use of repeated measures was not appropriate. Correlations between fruit $\mathrm{Ca}$ and fruit firmness within each cultivar using the pooled data were analyzed using PROC CORR.

\section{Results and Discussion}

\section{Expt. 1}

Targeted $\mathrm{Ca}$ applications did not impact leaf $\mathrm{Ca}$ at time of fruit harvest or fruit $\mathrm{Ca}$ concentration in any crop or cultivar (Table 4), nor were any changes in visual appearance or flavor of fruit detected at harvest (data not shown). Although a risk of phytotoxicity is mentioned in the literature, particularly when using $\mathrm{CaCl}_{2}$ (Chang et al., 2004; Cheour et al., 1990; Morris et al., 1980), we saw no evidence of fruit or leaf damage even at the highest concentration used $\left(0.3 \% \mathrm{CaCl}_{2}\right)$ in 'Albion'. Past studies in strawberry and blueberry have also shown that fruit $\mathrm{Ca}$ is not necessarily impacted by foliar $\mathrm{Ca}$ applications (Chen et al., 1998) even when leaf Ca was impacted (Hanson, 1995; Makus and Morris, 1989; Smith, 2016). No correlation was found between fruit $\mathrm{Ca}$ and firmness at harvest or after storage for any cultivar of any crop $(n=28$, data not shown).

Storage. There was no effect of Ca treatment on visual ratings of decay and nesting (loss of fruit integrity leading to collapse or 

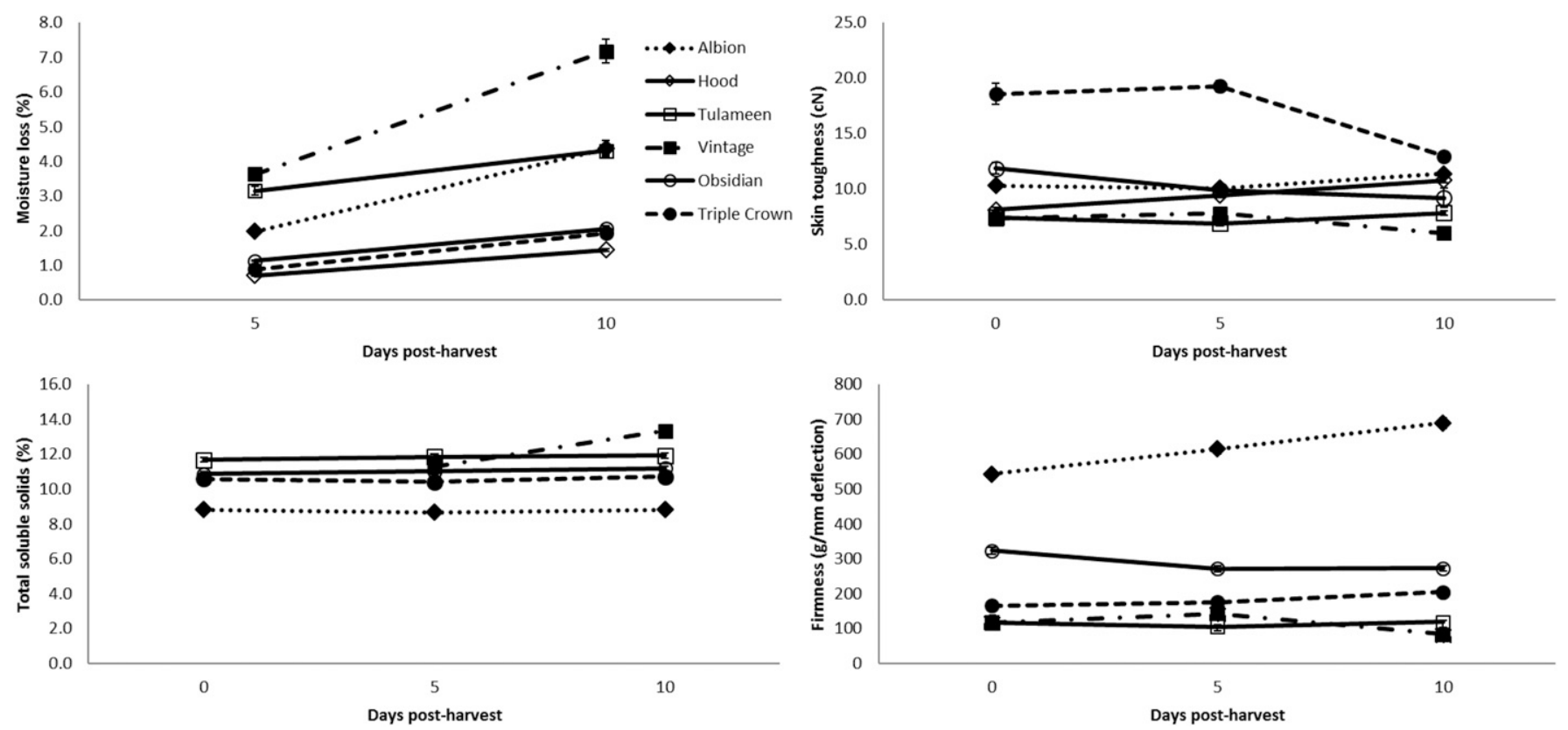

Fig. 1. Impact of strawberry ('Albion' and 'Hood'), raspberry ('Tulameen' and 'Vintage'), and blackberry ('Obsidian' and 'Triple Crown') cultivars on fruit (A) percent moisture loss, (B) skin toughness, (C) total soluble solids (\%TSS), and (D) firmness at 0- (day of harvest, no data for percent moisture loss), 5-, and 10 -d postharvest at location 1 (Cornelius, OR), averaged over foliar calcium treatment $(\mathrm{n}=28)$.

sinking) during storage for any crop/cultivar (data not shown) so the data were pooled.

Strawberry. In strawberry, fruit quality parameters, including firmness, skin toughness, berry weight or TSS, were unaffected by $\mathrm{Ca}$ applications. As expected, strawberry fruit lost more moisture as storage time increased. Interactions between cultivar and days of storage were found for percent moisture loss $(P<0.0001)$ and skin toughness $(P=0.0010)$ (Fig. 1A and B). There was no difference in TSS at harvest between the cultivars studied (Fig. 1C). In 'Albion', firmness increased significantly between time of harvest and $10-\mathrm{d}$ postharvest $(P<0.0001)$ (Fig. 1D), likely due to moisture loss, while TSS was not impacted by storage time. Cheour et al. (1990) found that Ca-treated strawberries (in which leaf and fruit $\mathrm{Ca}$ increased with at least one foliar application of 10 to $20 \mathrm{~kg} \cdot \mathrm{ha}^{-1} \mathrm{CaCl}_{2}$ ) maintained firmness during storage better than untreated berries, but when plants were grown with higher soil and tissue $\mathrm{Ca}$ levels, foliar $\mathrm{Ca}$ applications had a less pronounced effect. In another study, strawberry fruit TSS and $\mathrm{pH}$ were lower after $2 \mathrm{~d}$ of storage and decay was reduced by foliar $\mathrm{Ca}$ ( 21 applications of $\mathrm{Ca}$ trihydroxyglutarate at 7 or $\left.30 \mathrm{~kg} \cdot \mathrm{ha}^{-1}\right)$, but fruit $\mathrm{Ca}(\%)$ was unaffected (Makus and Morris, 1989). In 'Chandler' strawberry treated with $\mathrm{CaCl}_{2}$, only the highest concentration applied $(0.6 \%$, double the highest concentration used in the present trial) improved shelf life compared with a water sprayed control (Bakshi et al., 2013).

Raspberry. The few changes that were detected in raspberry fruit quality during storage were not consistent by treatment or cultivar; there was no effect of $\mathrm{Ca}$ treatment on any fruit quality parameter measured (data not shown). Eaves et al. (1972) also found that preharvest $\mathrm{Ca}$ sprays on raspberry did not have a strong impact on firmness at harvest, whereas berry softening and fruit rot were reduced after storage. In our study, interactions were found between cultivar and days of storage for percent moisture loss $(P<$ $0.0001)$, skin toughness $(P<0.0001)$, firmness $(P<0.0001)$, and TSS $(P<0.0001)$ (Fig. 1A-D). 'Vintage' fruit may have had a greater percent moisture loss than 'Tulameen' because clamshells were not filled completely, leaving more airspacea result of fewer ripe fruit available per plot at harvest. This also may have impacted firmness and skin toughness.

Blackberry. In blackberry, no effects of $\mathrm{Ca}$ treatment on fruit quality were seen (data not shown). Morris et al. (1980) reported blackberry fruit firmness was similar among untreated and foliar $\mathrm{Ca}$ treatments at harvest, but after 24-h storage, Ca-treated fruit were more firm. However, they found that cultivar had a large role in determining quality at harvest and after storage. In our study, TSS was only affected by cultivar $(P<0.0001)$ (Fig. 1C), whereas percent moisture loss was affected by both cultivar $(P=0.0003)$ and days of storage $(P<0.0001)$ (Fig. 1A). There was an interaction between cultivar and days of storage on skin toughness $(P<0.0001)$ and firmness $(P<0.0001)$. Although 'Triple Crown' had higher skin toughness than 'Obsidian' (Fig. 1B), it was less firm at harvest and throughout storage (Fig. 1D). Fernandez-Salvador et al. (2015a) found that organically grown 'Obsidian' fruit were firmer and had similar or lower TSS than 'Triple Crown', depending on year. 'Obsidian' also had the longest marketable storage days $\left(14 \mathrm{~d}\right.$ at $\left.5{ }^{\circ} \mathrm{C}\right)$ in the cultivars studied (Fernandez-Salvador et al., 2015b).

Blueberry. Fruit quality and shelf life were unaffected by the foliar $\mathrm{Ca}$ treatment applications in blueberry (data not shown). In general, all fruit samples stored well with little decay. There was insufficient ripe fruit of 'Draper' at location 2 to assess fruit quality and shelf life, though 'Draper' from location 3 had the firmest fruit and toughest skin of any blueberry cultivar tested. There was an interaction between cultivar and days of storage for percent moisture loss $(P<$ $0.0001)$, skin toughness $(P<0.0001)$, and firmness $(P<0.0001)$ (Fig. 2A-C), whereas TSS was not impacted by cultivar or storage time (Fig. 2D). 'Liberty' fruit were picked at a more advanced stage of fruit maturity at location 1 compared with location 2, perhaps explaining why 'Liberty' at location 2 had higher skin toughness and firmness. 'Spartan' had lower skin toughness and firmness than the other cultivars, demonstrating that it may be less suited to long-term storage for fresh market. 'Legacy' from Expt. 2 had among the lowest skin toughness and moderate firmness (Fig. 2B and C). 'Draper' had among the lowest fruit $\mathrm{Ca}$ (Table 5), but the highest fruit firmness, which suggests the relationship between fruit $\mathrm{Ca}$ and firmness may vary by cultivar. Angeletti et al. (2010) found that 'Bluecrop' had lower fruit $\mathrm{Ca}$ than 'O'Neal' but was more firm at harvest, and Strik and Vance (2015) found no apparent relationship between fruit $\mathrm{Ca}$ and grower experience and reports of firmness among many blueberry cultivars.

\section{Expt. 2}

Method of application and the corresponding difference in $\mathrm{Ca}$ concentration applied (Table 3) did not impact fruit or leaf $\mathrm{Ca}$ concentration (Table 5), or any aspect of fruit quality or shelf life (data not shown). Since the use of electrostatic sprayers is meant to improve coverage by spraying a mist of 

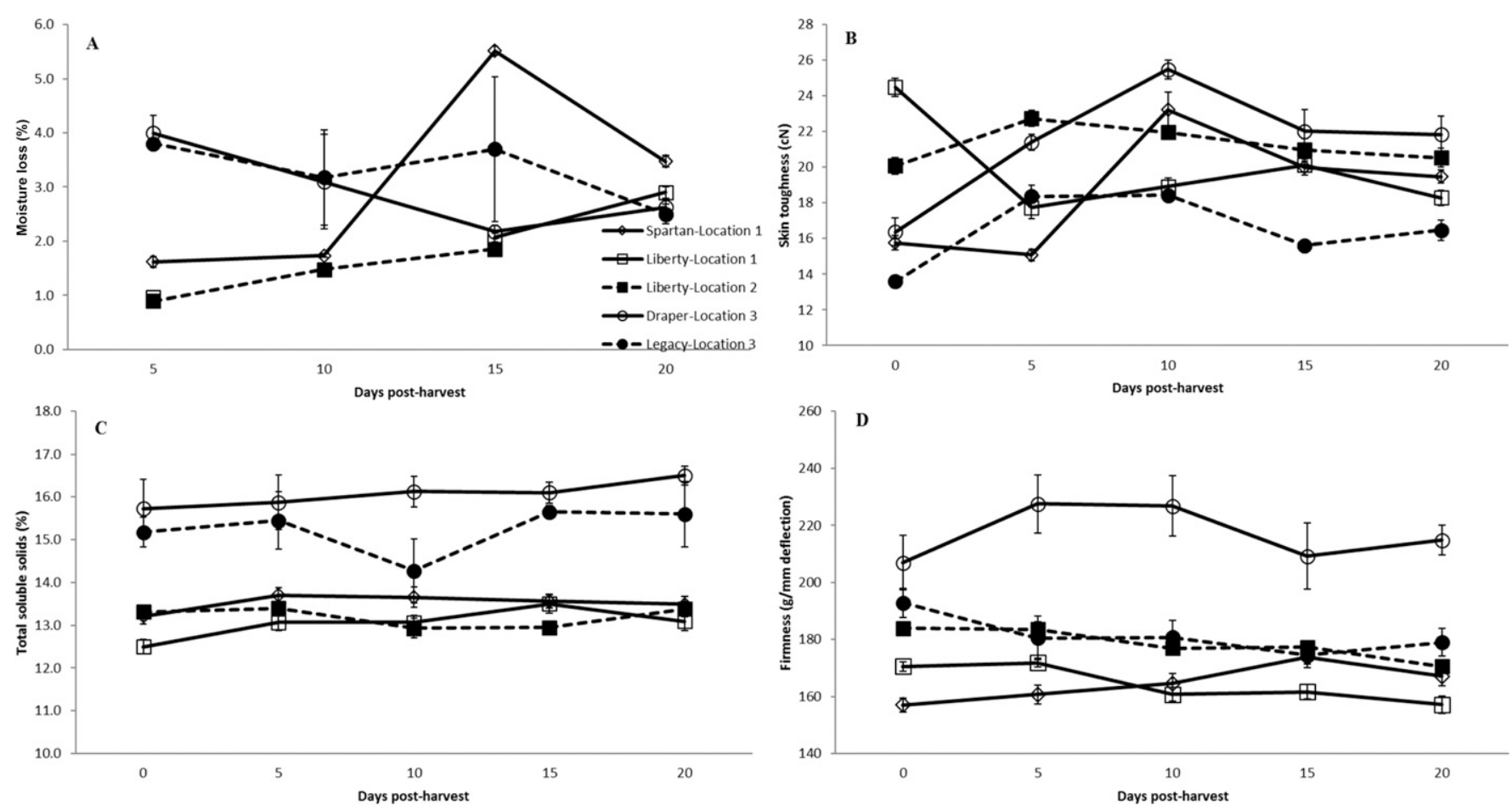

Fig. 2. Impact of blueberry cultivars ('Spartan', 'Draper', 'Liberty', and 'Legacy') in Expts. 1 and 2 at locations 1 (Cornelius, OR, $n=28), 2$ (Salem, OR, $n=28)$, and 3 (North Willamette Research and Extension Center, Aurora, OR, $n=4)$ on fruit $(\mathbf{A})$ percent moisture loss, $(\mathbf{B})$ skin toughness, $(\mathbf{C})$ total soluble solids (\%TSS), and (D) firmness at 0- (day of harvest, no data for percent moisture loss), 5-, 10-, 15-, and 20-d postharvest. Averaged over foliar calcium treatment at all locations and also over application method for Expt. 2, location $3(\mathrm{n}=4)$.

Table 5. Fruit and leaf calcium $(\mathrm{Ca}, \%)$ as impacted by cultivar and spray method in Expt. 2 at the North Willamette Research and Extension Center (Aurora, OR).

\begin{tabular}{lcc}
\hline & \multicolumn{2}{c}{$\% \mathrm{Ca}$} \\
\cline { 2 - 3 } Treatment & Fruit & Leaf \\
\hline Cultivar (CV) & 0.03 & 0.74 \\
$\quad$ Draper & 0.05 & 0.54 \\
$\quad$ Legacy & & \\
Spray method (Sm) & 0.04 & 0.64 \\
$\quad$ Backpack & 0.04 & 0.64 \\
$\quad$ Electrostatic & & \\
Significance & & \\
$\quad$ CV & 0.0138 & 0.0176 \\
$\quad$ Sm & NS & NS \\
CV $\times$ Sm & NS & NS \\
\hline $\mathrm{z}^{\mathrm{z}} P$ value provided; Ns
\end{tabular}

${ }^{\mathrm{z}} P$ value provided; ${ }^{\text {s }}$ nonsignificant at $P>0.05$

charged droplets that wrap around and adhere to all leaf and berry surfaces (Law, 1983), it was expected that $\mathrm{Ca}$ concentration would increase more than when using a backpack sprayer with larger, uncharged droplets primarily reaching the outer surfaces of the plant. Lower volumes of both water and product applied can often be used with electrostatic sprayers to achieve similar or better results compared with conventional air blast sprayers (Law and Scherm, 2005). However, since no formulation or concentration of $\mathrm{Ca}$ was successful at increasing fruit or leaf $\mathrm{Ca}$ in Expt. 1, there may be other factors preventing the movement of $\mathrm{Ca}$ into the plants even with improved leaf and fruit coverage from the electrostatic sprayer.

In strawberry, Cheour et al. (1990) found that one application of $\mathrm{Ca}$ did increase leaf tissue $\mathrm{Ca}$, but subsequent applications did not further increase leaf $\mathrm{Ca}$. They hypothesized that $\mathrm{Ca}$ treatments are only effective when tissue levels are below a sufficiency level. Studies in apple have shown that $\mathrm{CaCl}_{2}$ more readily penetrates the skin early in fruit development compared with later in the season, likely due to an increased number and functionality of stomata (Schlegel and Schonherr, 2002). Since there is not a good understanding of stomatal function in berry crop leaves or fruit, we do not know the ideal timing or frequency at which $\mathrm{Ca}$ would need to be applied to achieve higher leaf and fruit $\mathrm{Ca}$. The use of surfactants can increase the efficacy of sprays by increasing contact between spray droplets and the leaf and fruit surfaces (Fernandez and Eichert, 2009; Schlegel and Schonherr, 2002); however, none of the applied product labels provided recommendations on surfactants and growers rarely use surfactants when applying these products.

\section{Conclusions}

Targeted calcium applications at the rates currently recommended by the label of the products used $(0.05 \%$ to $0.30 \% \mathrm{Ca}$, depending on product and volume of water applied per hectare) were not effective at increasing fruit or leaf $\mathrm{Ca}$ concentration or altering fruit quality at harvest and during storage. Method of application also did not impact $\mathrm{Ca}$ concentration or fruit quality in blueberry. Aspects of fruit quality and shelf life were dependent on cultivar.

\section{Literature Cited}

Angeletti, P., H. Castagnasso, E. Miceli, L. Terminiello, A. Concellon, A. Chaves, and A.R. Vicente. 2010. Effect of preharvest calcium applications on postharvest quality, softening and cell wall degradation of two blueberry (Vaccinium corymbosum) varieties. Postharvest Biol. Technol. 58:98-103.

Bakshi, P., A. Jasrotia, V.K. Wali, A. Sharma, and M. Bakshi. 2013. Influence of pre-harvest application of calcium and micro-nutrients on growth, yield, quality and shelf-life of strawberry cv. Chandler. Indian J. Agr. Sci. 83:831835.

Bangerth, F. 1979. Calcium-related physiological disorders of plants. Annu. Rev. Phytopathol. 17:97-122.

Barney, D.L., P. Bristow, C. Cogger, S.M. Fitzpatrick, J. Hart, D. Kaufman, C. Miles, T. Miller, P.P. Moore, T. Murray, H. Rempel, B. Strik, and L. Tanigoshi. 2007. Commercial red raspberry production in the Pacific Northwest. Pacific Northwest Extension: PNW 598.

Chang, Y.C., K. Grace-Martin, and W.B. Miller. 2004. Efficacy of exogenous calcium application for reducing upper leaf necrosis in Lilium 'Star Gazer'. HortScience 39:272-275.

Chen, Y., J.M. Smagula, W. Litten, and S. Dunham. 1998. Effect of boron and calcium foliar sprays on pollen germination and development, fruit set, seed development, and berry yield and quality in lowbush blueberry (Vaccinium angustifolium Ait.). J. Amer. Soc. Hort. Sci. 123:524-531.

Cheour, F., C. Willemot, J. Arul, Y. Desjardins, J. Makhlouf, P.M. Charest, and A. Gosselin. 1990. Foliar application of calcium chloride delays postharvest ripening of strawberry. J. Amer. Soc. Hort. Sci. 115:789-792.

Eaves, C.A., C.L. Lockhart, R. Stark, and D.L. Craig. 1972. Influence of preharvest sprays of 
calcium salts and wax on fruit quality of red raspberry. J. Amer. Soc. Hort. Sci. 97:706-707.

Fernandez, V. and T. Eichert. 2009. Uptake of hydrophilic solutes through plant leaves: Current state of knowledge and perspectives of foliar fertilization. Crit. Rev. Plant Sci. 28:36-68.

Fernandez-Salvador, J., B.C. Strik, and D.R. Bryla. 2015a. Response of blackberry cultivars to fertilizer source during establishment in an organic fresh market production system. HortTechnology 25:277-292.

Fernandez-Salvador, J., B.C. Strik, Y. Zhao, and C.E. Finn. 2015b. Trailing blackberry genotypes differ in yield and post-harvest fruit quality during establishment in an organic production system. HortScience 50:240-246.

Gavlak, R.G., D.A. Horneck, and R.O. Miller. 1994. Plant, soil, and water reference methods for the western region. Western Reg. Ext. Pub. 125 (WREP-125), Univ. Alaska, Fairbanks, AK.

Hanson, E.J. 1995. Preharvest calcium sprays do not improve highbush blueberry (Vaccinium corymbosum L.) quality. HortScience 30:977978.

Hanson, E.J., J.L. Beggs, and R.M. Beaudry. 1993. Applying calcium chloride postharvest to improve highbush blueberry firmness. HortScience 28:1033-1034.

Harkins, R.H., B.C. Strik, and D.R. Bryla. 2014. Weed management practices for organic production of trailing blackberry. II. Accumulation and loss of biomass and nutrients. HortScience 49:35-43.
Hoashi-Erhardt, W. and T. Walters. 2014. Growing day-neutral strawberries in western Washington. Washington State University Extension Fact Sheet FS132E.

Law, S.E. 1983. Electrostatic pesticide spraying: Concepts and practice. IEEE Trans. Ind. Appl. IA-19:160-168.

Law, S.E. and H. Scherm. 2005. Electrostatic application of a plant-disease biocontrol agent for prevention of fungal infection through the stigmatic surfaces of blueberry flowers. J. Electrost. 63:399-408.

Makus, D.J. and J.R. Morris. 1989. Influence of soil and foliar applied calcium on strawberry fruit nutrients and post-harvest quality. Acta Hort. 265:443-446.

Montealegre, J.R. and J.M. Valdes. 1993. The effect of calcium applied before harvest on the susceptibility of raspberry fruits to Botrytis cinerea. Fitopatologia 28:93-96.

Morris, J.R., D.L. Cawthon, G.S. Nelson, and P.E. Cooper. 1980. Effects of preharvest calcium sprays and postharvest holding on firmness and quality of machine-harvested blackberries. HortScience 15:33-34.

Pscheidt, J.W. and C.M. Ocamb. (senior editors). 2016. Pacific Northwest plant disease management handbook (online). Oregon State University, Corvallis, OR. 6 Oct 2016. <https:// pnwhandbooks.org/plantdisease $>$.

Saure, M.C. 2005. Calcium translocation to fleshy fruit: Its mechanism and endogenous control. Sci. Hort. 105:65-89.

Schlegel, T.K. and J. Schonherr. 2002. Stage of development affects penetration of calcium chloride into apple fruits. J. Plant Nutr. Soil Sci. 165:738-745.

Singh, R., R.R. Sharma, and S.K. Tyagi. 2007. Preharvest foliar application of calcium and boron influences physiological disorders, fruit yield and quality of strawberry (Fragaria $\times$ ananassa Duch.). Sci. Hort. 112:215-220.

Smith, E.D. 2016. The effect of foliar calcium treatments on fruit weight and firmness of rabbiteye blueberry (Vaccinium virgatum Aiton). J. Amer. Pomol. Soc. 70:74-81.

Strik, C., C. Brun, M. Ahmedullah, A. Antonelli, L. Askham, D. Barney, P. Bristow, G. Fisher, J. Hart, D. Havens, R. Ingham, D. Kaufman, R. Penhallegon, J. Pscheidt, B. Scheer, C. Shanks, and R. William. 1993. Highbush blueberry production. Oregon State. Univ. Ext. Serv. Pub. PNW 215.

Strik, B.C. and A.J. Vance. 2015. Seasonal variation in leaf nutrient concentration of northern highbush blueberry cultivars grown in conventional and organic production systems. HortScience 50:1453-1466.

USDA National Agricultural Statistics Service. 2015. Noncitrus Fruits and Nuts 2014 Summary, July 2015. 22 Apr. 2016. <http://usda. mannlib.cornell.edu/usda/current/NoncFruiNu/ NoncFruiNu-07-17-2015.pdf $>$.

Van-Buren, J.P. 1979. The chemistry of texture in fruits and vegetables. J. Texture Stud. 10:1-23.

Wójcik, P. and M. Lewandowski. 2003. Effect of calcium and boron sprays on yield and quality of 'Elsanta' strawberry. J. Plant Nutr. 26:671682 . 